\title{
The efficacy of neem seed extract (Azadirachta indica) to control tick infestation in Tswana, Simmentaler and Brahman cattle
}

\author{
E.C.Webb ${ }^{\# 1}$ and M. David ${ }^{2}$ \\ ${ }^{1}$ Department of Animal and Wildlife Sciences, University of Pretoria, Pretoria 0002, South Africa \\ ${ }^{2}$ Serowe College of Education, Private Bag 009, Serowe, Botswana
}

\begin{abstract}
The aim of this experiment was to evaluate the use of neem seed extract for controlling common cattle ticks of the Ixodidae species. Three bulls and three cows of the Tswana, Brahman and Simmentaler breeds were cleared of ticks using ether and hand-picking techniques. Each animal was then naturally infested with ticks. A $5 \%(\mathrm{w} / \mathrm{v})$ water extract of neem seed kernel was applied at a rate of $5 \mathrm{~g} / \mathrm{kg}$ body weight to various anatomical sites on the animals allocated to the experimental treatment, while the control treatment animals were sprayed with tap water. Treated and control animals grazed together and were mustered at weekly intervals for examination. Tick population densities on animals treated with neem seed extract were lower than on untreated animals. Indigenous Tswana cattle harboured fewer ticks during periods of tick abundance than Brahman or Simmentaler cattle. It was concluded that neem seed extract is effective in controlling ectoparasites on livestock.
\end{abstract}

Keywords: Ticks, cattle, neem seed extract

${ }^{\#}$ Corresponding author. e-mail: ecwebb@postino.up.ac.za

\section{Introduction}

Common cattle ticks of the Ixodidae species are vectors of animal disease and can cause decreased animal productivity, especially in developing countries where control measures are not carried out regularly (Farbeni, 1983; Kilonzo, 1986). Several investigations have shown that an extract from the seeds of the neem tree (Azadirachta indica) has insect repellent properties and inhibits the development and growth in insects (Jotwarni \& Sirca, 1965; Butterworth \& Morgan, 1971). The neem tree belongs to the family Meliacea and is widely distributed in Asia, Africa and other tropical parts of the world. A number of compounds has been isolated from various parts of the tree, viz. meliantriol, salannin, azadirachtin and the triterpenoids, nimocinolide and isonimocinolide (Siddique et al., 1986). Neem extract seems to disrupt the mating and oviposition of insects and inhibits the hatchability of their eggs and moulting of their nymphs (Rembold et al., 1986; Sazena, 1993). Generally, farmers in Botswana do not apply management programmes to control ectoparasites on their livestock. Although most of the commonly available insecticides are effective against ticks in Botswana, their use is restricted because of high costs and fears of contamination of the environment and potential toxic effects on humans and other non-target organisms. There is a need for alternative tick control measures that are effective, safe and economically and environmentally acceptable. Natural plant products would be suitable candidates. Azadirachta indica has proven to be effective against many insect pests and disease vectors of agricultural products (Wilps, 1986; Zebitz, 1986; Schmutterer, 1990) and is widely distributed in many parts of Africa, especially in the dry areas where livestock farming is common. In view of their potential larvicidal effects, the use and effectiveness of an extract from the neem seed kernel (NSK) to control ticks on cattle were investigated.

\section{Materials and methods}

The experiment was conducted from November 1998 to December 1999 on farms at Serowe village $\left(22^{\circ} 22^{\prime} \mathrm{S}, 2^{\circ} 42^{\prime} \mathrm{E}\right)$ near Gaborone, Botswana. The total rainfall during 1998 and 1999 was $311 \mathrm{~mm}$ and 337 $\mathrm{mm}$ respectively. Average number of ticks per month on the cattle, monthly rainfall and minimum and maximum temperatures $\left({ }^{\circ} \mathrm{C}\right)$ recorded by the Botswana Meteorological Service during the study period are presented in Figure 1. There are three distinct seasons in Botswana, viz. dry winter (April to July), rainy summer (November to March) and spring (August to October). 

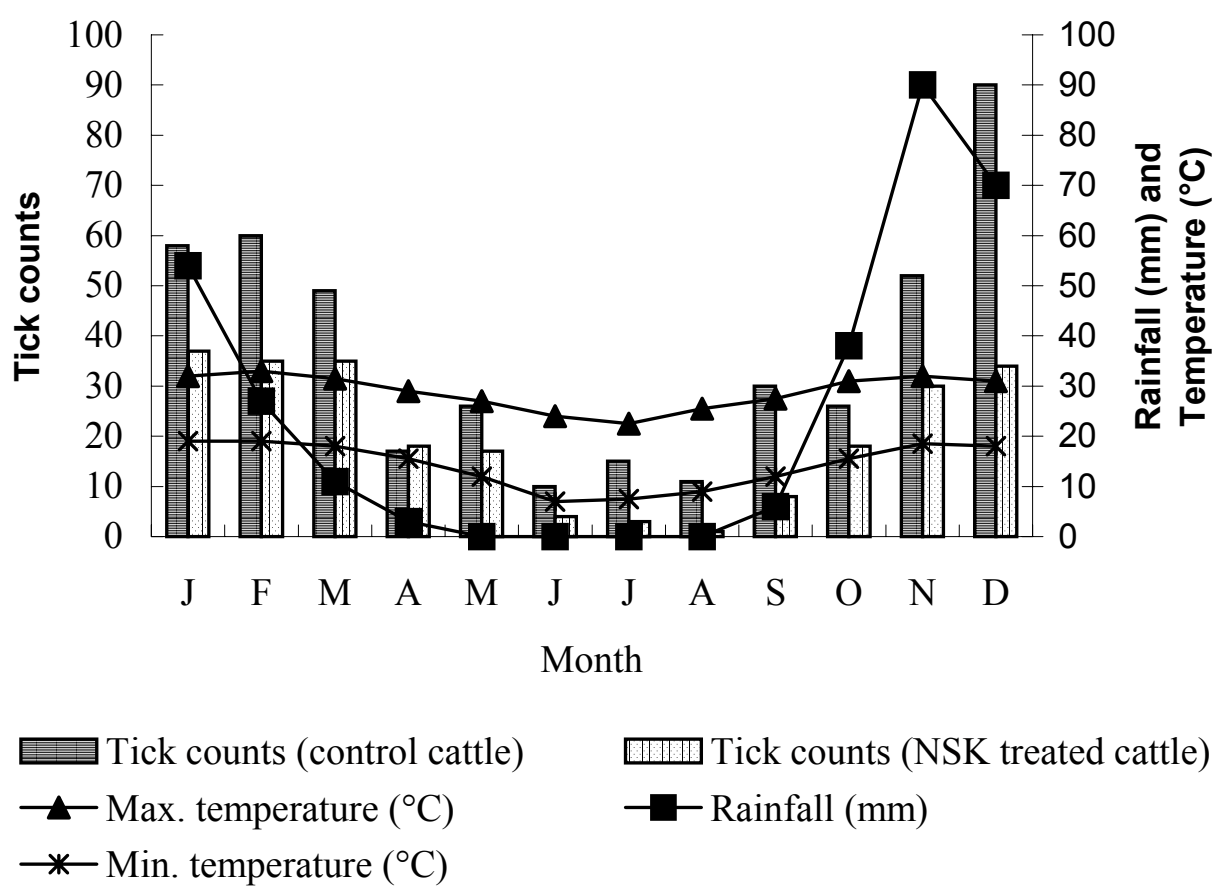

$\square$ Tick counts (NSK treated cattle)
$\rightarrow-$ Rainfall (mm)

Figure 1 Mean monthly rainfall $(\mathrm{mm})$, minimum and maximum temperatures $\left({ }^{\circ} \mathrm{C}\right)$ and mean number of engorged female ticks per month on cattle treated with either $5 \%(\mathrm{w} / \mathrm{v})$ water extract of neem seed kernel (NSK) at a rate of $5 \mathrm{~g} / \mathrm{kg}$ body weight or sprayed with tap water (control)

A total of 18 cattle, viz. three bulls and three cows each of the Tswana, Brahman and Simmentaler breeds, of $c$. 15 months of age were obtained from two smallholder farmers at Serowe. None of the animals were treated with acaricides prior to this experiment. The cattle were cleared of ticks using ether and handpicking techniques. A $5 \%(\mathrm{w} / \mathrm{v})$ water extract of neem seed kernel was then applied at a rate of $5 \mathrm{~g} / \mathrm{kg}$ body weight to various anatomical sites on the animals allocated to the experimental treatment, while the control treatment animals were sprayed with tap water. Experimental animals were allocated to different treatments in a fully randomised block design. The treated and control animals grazed together in an area which was heavily infested with adult and immature ticks. All animals were treated at weekly intervals. Before treatment the number of engorged female ticks was counted on the perineal area, belly, external ear, udder, scrotum and sternum of the cattle. Ticks were preserved in $70 \%$ ethanol prior to species identification using stereo microscopy.

Neem seed kernels were obtained from ripe seeds. The kernels were thoroughly dried in the sun, crushed to a fine powder using a wooden mortar and pestle, sieved through a $30 \mathrm{~mm}$ mesh and dissolved in water. Some seeds were processed in an oil-extraction apparatus.

Differences between treatments, breeds, anatomical sites, genders and seasons were analysed using the GLM-repeated measures analysis procedure of SAS (1992).

\section{Results and discussion}

Tick counts were lower $(\mathrm{P}<0.01)$ on the animals treated with neem extract (Figure 1 and Table 1) compared to the control animals treated with water. Average tick counts were $37.5 \pm 12.75$ for control animals and $19.75 \pm 12.75$ for treated animals. A variety of tick species was present throughout the year with marked peaks of abundance during the warmer months of the year (November and December; Figure 1). The number of engorged female ticks appeared to vary in synchrony with the rainfall (Figure 1). A similar trend was evident in the research of Spickett et al. (1989). Seasonal variations in the number of engorged Amblyomma hebreaum, Rhipicephalus evertsi, Hyalomma truncatum and Boophilus decoloratus females on Simmentaler, Brahman and Tswana cattle are presented in Figures 2, 3, 4 and 5. More A. hebraeum ticks were counted on all three breeds of cattle during the rainy season in summer $(\mathrm{P}<0.0001$, Figure 2$)$ than in 
Table 1 Effects of neem treatment, breed and anatomical site on the number of engorged female Amblyomma hebreaum, Hyalomma truncatum, Rhipicephalus evertsi and Boophilus decoloratus ticks on cattle

\begin{tabular}{|c|c|c|c|c|c|c|c|c|c|c|}
\hline \multirow[b]{2}{*}{ Tick species } & & \multicolumn{3}{|c|}{ Simmentaler } & \multicolumn{3}{|c|}{ Brahman } & \multicolumn{3}{|c|}{ Tswana } \\
\hline & & Neem & Control & Difference* & Neem & Control & Difference* & Neem & Control & Difference* \\
\hline \multirow[t]{6}{*}{ A. hebreaum } & Perineal & $9 \pm 1.0^{\mathrm{a}}$ & $16 \pm 0.8^{b}$ & \multirow{10}{*}{$56 \%$} & $6 \pm 1.1^{\mathrm{c}}$ & $12 \pm 2.1^{\mathrm{d}}$ & & $4 \pm 0.8^{\mathrm{e}}$ & $7 \pm 1.0^{\mathrm{c}}$ & \multirow{10}{*}{$77 \%$} \\
\hline & Belly & $8 \pm 1.0^{\mathrm{a}}$ & $20 \pm 2.2^{b}$ & & $9 \pm 0.6^{\mathrm{a}}$ & $15 \pm 1.4^{\mathrm{d}}$ & & $2 \pm 0.5^{\mathrm{e}}$ & $6 \pm 0.6^{\mathrm{f}}$ & \\
\hline & Sternum & $3 \pm 0.6^{\mathrm{a}}$ & $13 \pm 1.2^{\mathrm{b}}$ & & $5 \pm 0.7^{c}$ & $8 \pm 0.5^{\mathrm{d}}$ & & $0 \pm 0.0^{\mathrm{e}}$ & $5 \pm 0.8^{c}$ & \\
\hline & Udder & $2 \pm 0.6^{\mathrm{a}}$ & $4 \pm 1.5^{\mathrm{b}}$ & & $1 \pm 0.6^{\mathrm{a}}$ & $6 \pm 1.7^{b}$ & & $0 \pm 0.0^{\mathrm{c}}$ & $4 \pm 1.2^{b}$ & \\
\hline & Ear & $4 \pm 0.5^{\mathrm{a}}$ & $9 \pm 1.3^{b}$ & & $4 \pm 0.8^{\mathrm{a}}$ & $6 \pm 0.6^{\mathrm{c}}$ & & $0 \pm 0.0^{\mathrm{d}}$ & $2 \pm 0.5^{\mathrm{f}}$ & \\
\hline & Scrotum & $3 \pm 1.0^{\mathrm{a}}$ & $4 \pm 1.5^{\mathrm{a}}$ & & $4 \pm 0.0^{\mathrm{a}}$ & $1 \pm 0.6^{\mathrm{b}}$ & $30 \%$ & $0 \pm 0.0^{\mathrm{c}}$ & $2 \pm 0.5^{\mathrm{a}}$ & \\
\hline \multirow[t]{6}{*}{ H. truncatum } & Perineal & $6 \pm 0.9^{\mathrm{a}}$ & $11 \pm 1.9^{b}$ & & $7 \pm 0.7^{\mathrm{a}}$ & $13 \pm 1.3^{\mathrm{b}}$ & & $6 \pm 0.6^{\mathrm{a}}$ & $4 \pm 1.0^{\mathrm{a}}$ & \\
\hline & Belly & $12 \pm 1.4^{\mathrm{a}}$ & $22 \pm 1.6^{\mathrm{b}}$ & & $10 \pm 1.0^{\mathrm{a}}$ & $12 \pm 1.5^{\mathrm{a}}$ & & $3 \pm 0.6^{\mathrm{c}}$ & $10 \pm 1.0^{\mathrm{a}}$ & \\
\hline & Sternum & $8 \pm 1.0^{\mathrm{a}}$ & $21 \pm 1.4^{b}$ & & $6 \pm 1.1^{\mathrm{a}}$ & $12 \pm 1.1^{\mathrm{b}}$ & & $2 \pm 0.5^{\mathrm{c}}$ & $5 \pm 0.7^{\mathrm{a}}$ & \\
\hline & Udder & $4 \pm 0.6^{\mathrm{a}}$ & $8 \pm 1.5^{\mathrm{b}}$ & & $2 \pm 0.5^{\mathrm{c}}$ & $4 \pm 0.6^{\mathrm{a}}$ & & $1 \pm 0.6^{\mathrm{d}}$ & $3 \pm 0.0^{\mathrm{a}}$ & \\
\hline & Ear & $4 \pm 0.8^{\mathrm{a}}$ & $8 \pm 1.4^{b}$ & \multirow[b]{2}{*}{$51 \%$} & $3 \pm 0.6^{\mathrm{a}}$ & $4 \pm 0.8^{\mathrm{a}}$ & \multirow[b]{2}{*}{$36 \%$} & $1 \pm 0.4^{\mathrm{c}}$ & $0 \pm 0.0^{\mathrm{d}}$ & \multirow[b]{2}{*}{$40 \%$} \\
\hline & Scrotum & $2 \pm 1.2^{\mathrm{a}}$ & $3 \pm 1.0^{\mathrm{a}}$ & & $2 \pm 0.5^{\mathrm{a}}$ & $2 \pm 0.5^{\mathrm{a}}$ & & $1 \pm 0.7^{\mathrm{b}}$ & $1 \pm 0.6^{\mathrm{b}}$ & \\
\hline \multirow[t]{6}{*}{ R. evertsi } & Perineal & $5 \pm 0.7^{\mathrm{a}}$ & $6 \pm 0.9^{\mathrm{a}}$ & \multirow{10}{*}{$50 \%$} & $3 \pm 0.6^{\mathrm{b}}$ & $4 \pm 0.8^{\mathrm{ab}}$ & & $2 \pm 0.5^{\mathrm{c}}$ & $1 \pm 0.4^{\mathrm{c}}$ & \multirow{12}{*}{$40 \%$} \\
\hline & Belly & $3 \pm 1.4^{\mathrm{a}}$ & $8 \pm 0.8^{b}$ & & $5 \pm 0.4^{c}$ & $5 \pm 0.7^{\mathrm{c}}$ & & $2 \pm 0.5^{\mathrm{a}}$ & $5 \pm 0.4^{c}$ & \\
\hline & Sternum & $5 \pm 1.0^{\mathrm{a}}$ & $7 \pm 0.9^{b}$ & & $7 \pm 0.7^{b}$ & $7 \pm 0.7^{b}$ & & $1 \pm 0.4^{\mathrm{c}}$ & $4 \pm 0.5^{\mathrm{a}}$ & \\
\hline & Udder & $2 \pm 0.5^{\mathrm{a}}$ & $4 \pm 1.5^{b}$ & & $0 \pm 0.0^{\mathrm{c}}$ & $1 \pm 0.5^{\mathrm{c}}$ & & $1 \pm 0.6^{\mathrm{c}}$ & $2 \pm 0.6^{c}$ & \\
\hline & Ear & $0 \pm 0.8^{\mathrm{a}}$ & $6 \pm 2.0^{b}$ & & $1 \pm 0.4^{\mathrm{a}}$ & $1 \pm 0.4^{\mathrm{a}}$ & & $1 \pm 0.4^{\mathrm{a}}$ & $3 \pm 0.6^{\mathrm{c}}$ & \\
\hline & Scrotum & $2 \pm 1.2^{\mathrm{a}}$ & $3 \pm 0.0^{\mathrm{a}}$ & & $1 \pm 0.6^{\mathrm{b}}$ & $1 \pm 0.5^{\mathrm{b}}$ & $10 \%$ & $0 \pm 0.0^{\mathrm{c}}$ & $0 \pm 0.0^{\mathrm{c}}$ & \\
\hline \multirow[t]{6}{*}{ B.decoloratus } & Perineal & $8 \pm 1.0^{\mathrm{a}}$ & $14 \pm 1.2^{\mathrm{b}}$ & & $5 \pm 0.7^{\mathrm{c}}$ & $9 \pm 1.6^{\mathrm{a}}$ & & $1 \pm 0.4^{\mathrm{d}}$ & $3 \pm 0.6^{\mathrm{e}}$ & \\
\hline & Belly & $5 \pm 0.7^{\mathrm{a}}$ & $12 \pm 1.3^{\mathrm{b}}$ & & $4 \pm 0.8^{\mathrm{a}}$ & $7 \pm 0.9^{c}$ & & $1 \pm 0.4^{\mathrm{d}}$ & $3 \pm 0.5^{\mathrm{e}}$ & \\
\hline & Sternum & $4 \pm 0.7^{\mathrm{a}}$ & $9 \pm 0.5^{\mathrm{b}}$ & & $6 \pm 0.0^{c}$ & $11 \pm 0.4^{\mathrm{d}}$ & & $1 \pm 0.4^{\mathrm{e}}$ & $4 \pm 0.5^{\mathrm{a}}$ & \\
\hline & Udder & $2 \pm 0.6^{\mathrm{a}}$ & $3 \pm 0.0^{\mathrm{a}}$ & & $0 \pm 0.0^{\mathrm{b}}$ & $3 \pm 1.00^{\mathrm{a}}$ & & $0 \pm 0.0^{\mathrm{b}}$ & $2 \pm 0.6^{\mathrm{a}}$ & \\
\hline & Ear & $4 \pm 0.8^{\mathrm{a}}$ & $7 \pm 1.0^{\mathrm{b}}$ & \multirow[b]{2}{*}{$51 \%$} & $4 \pm 0.5^{\mathrm{a}}$ & $3 \pm 0.8^{\mathrm{c}}$ & \multirow[b]{2}{*}{$34 \%$} & $0 \pm 0.0^{\mathrm{d}}$ & $1 \pm 0.4^{\mathrm{e}}$ & \\
\hline & Scrotum & $2 \pm 1.1^{\mathrm{a}}$ & $6 \pm 2.0^{\mathrm{b}}$ & & $4 \pm 0.5^{\mathrm{c}}$ & $2 \pm 0.6^{\mathrm{a}}$ & & $0 \pm 0.0^{\mathrm{d}}$ & $2 \pm 0.0^{\mathrm{a}}$ & \\
\hline
\end{tabular}

a,b,c,d,e, $\mathrm{f}$ Means in the same row without common superscripts differ $(\mathrm{P}<0.05)$

* Percentage difference in tick counts between treated and control animals

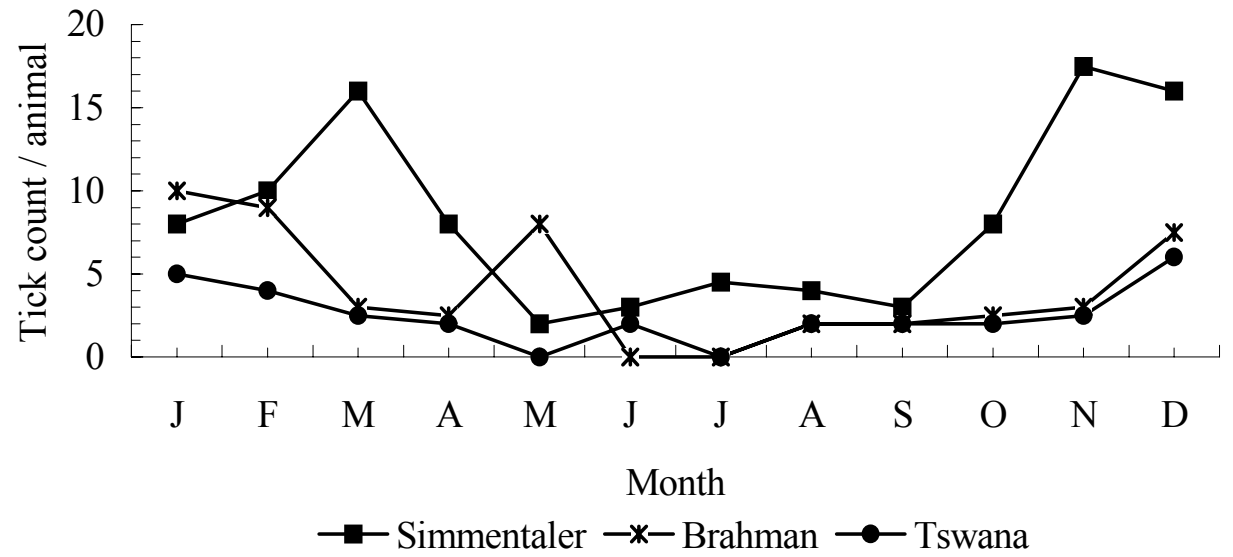

Figure 2 Mean monthly number of engorged Amblyomma hebraeum females on Simmentaler, Brahman and Tswana cattle

the dry season. Minor differences in the number of $A$. hebraeum ticks were observed between Simmentaler and Brahman cattle during the first year of the study, but in the summer months both these breeds were 
infested with more $(\mathrm{P}<0.05)$ ticks than the Tswana cattle. Lower counts of $A$. hebraeum ticks were recorded for all three breeds during the dry winter months than in summer.

Mean population densities of $R$. evertsi ticks were lower in the neem-treated than control animals $(\mathrm{P}<$ 0.05). Peak numbers of engorged female $R$. evertsi ticks were evident during the summer months (December 1998, March 1999 and December 1999). The trend was similar in all three breeds of cattle (Figure 3). The numbers of $R$. evertsi ticks on Simmentaler and Brahman cattle were higher $(\mathrm{P}<0.05)$ than on Tswana cattle. Fewer $R$. evertsi ticks were present on all three breeds of cattle during winter and spring $(\mathrm{P}<0.05)$ than in summer.

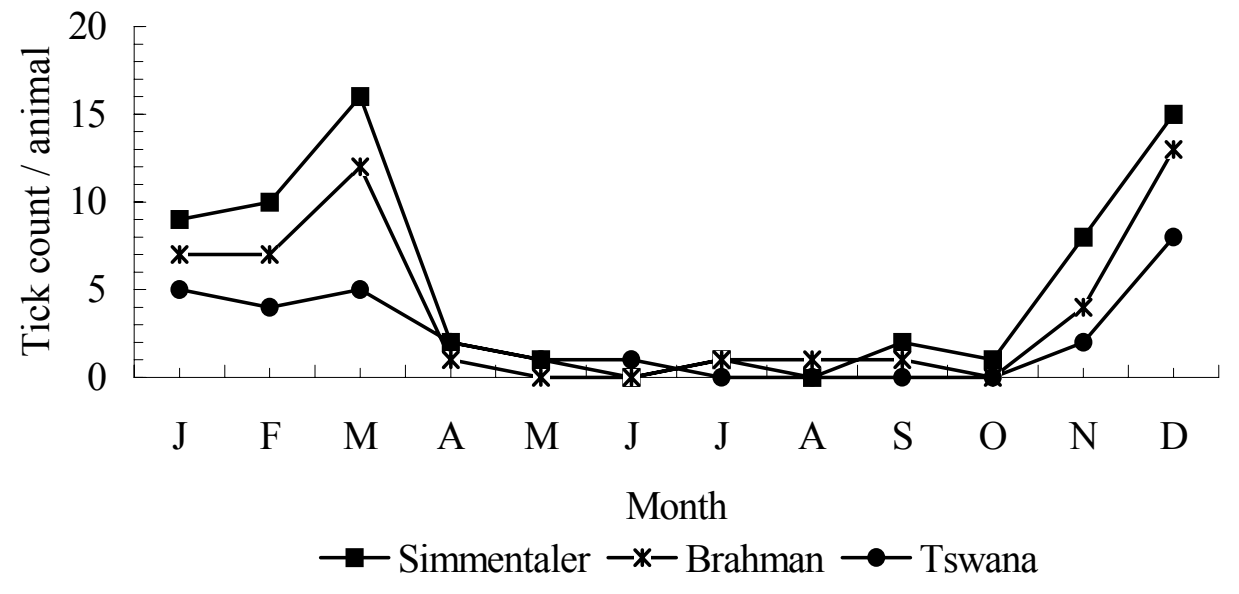

Figure 3 Mean monthly number of engorged Rhipicephalus.evetsi females on Simmentaler, Brahman and Tswana cattle

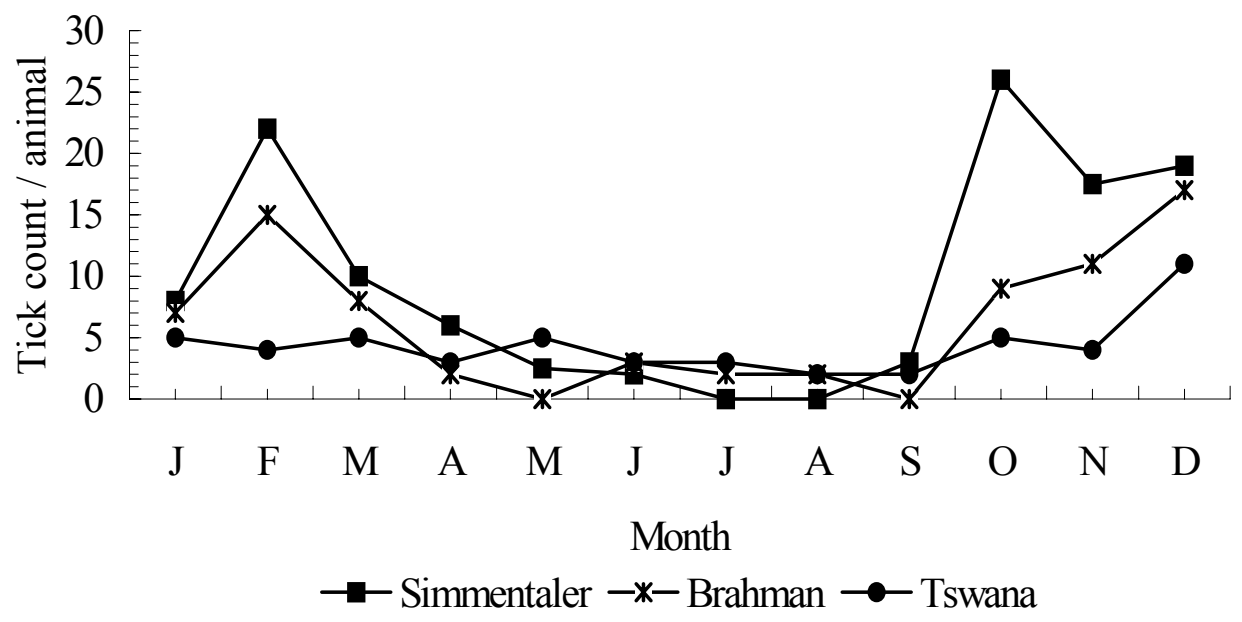

Figure 4 Mean monthly number of engorged Hyalomma truncatum females on Simmentaler, Brahman and Tswana cattle

Peak number of engorged female H. truncatum was observed in February and October of the second year (Figure 4). The Simmentaler cattle were infested with more engorged female ticks than the Brahman and Tswana cattle $(\mathrm{P}<0.0002)$. 
Insignificant differences were found between the number of engorged $B$. decoloratus ticks on Simmentaler and Brahman cattle. The ticks occurred throughout the year with peak numbers in March and September (Figure 5). Fewer engorged B. decoloratus females were observed than any other species of tick $(\mathrm{P}<0.05)$. During the winter no difference was observed in tick counts between neem- treated and control animals.

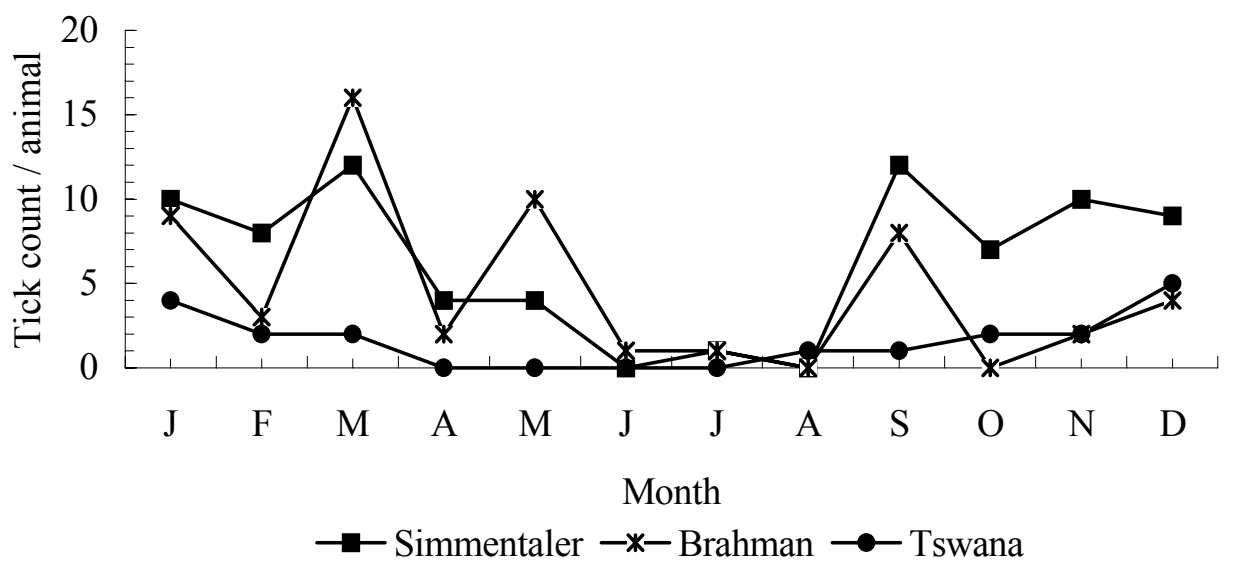

Figure 5 Mean monthly number of engorged Boophilus decoloratus females on Simmentaler, Brahman and Tswana cattle

Neem treatment reduced $(\mathrm{P}<0.01)$ the number of engorged female ticks (Table 1 and Figure 1$)$ on cattle. These results agreed with those of Jotwarni \& Sirca (1965) and Butterworth \& Morgan (1971). There were large differences $(\mathrm{P}<0.05)$ in tick counts between breeds (Table 1). Counts of engorged female ticks over the one-year period showed that indigenous Tswana cattle harboured fewer ticks during periods of peak infestation compared to both the Brahman and the Simmentaler cattle breeds. The results suggested that Tswana cattle have a natural tick resistance while the other two breeds did not show this potential to the same extent. These results are in agreement with Norval et al. (1988). Scholtz et al. (1989), Spickett et al. (1989) and Scholtz et al. (1991) also reported differences in tick resistance between Hereford, Bonsmara and Nguni cattle in South Africa. Based on the percentage difference in tick counts, it appears as if the ticks on the Brahman were least affected by the neem extract treatment (Table 1).

Ticks were found at all anatomical sites regardless of breed or sex. Tick counts differed between the various anatomical sites $(\mathrm{P}<0.01)$. More ticks were found on the belly, perineal area and sternum while fewer ticks were found on the udder and scrotum. In general, more ticks were observed on sites with long hair. Simmentaler cattle, which had the highest tick counts, also had longer hair than the other breeds, suggesting that animals with longer hair are more prone to tick infestation. However, Spickett et al. (1989) reported a poor correlation between hair length and tick count. This aspect requires further study. There was no difference in the number of ticks between sexes, although Tswana bulls appeared to be more resistant than cows $(\mathrm{P}<0.08)$.

Season affected the tick counts on cattle $(\mathrm{P}<0.01)$. The highest number of engorged female ticks was recorded during the summer months. This is probably because ticks breed during the rainy season when the ambient temperature is high. There was no difference between tick counts in winter $v s$. spring.

\section{Conclusions}

Neem seed extract is potentially useful for controlling ticks on livestock because it is a cheap natural insecticide that can play a significant role in reducing the indiscriminate use of synthetic chemicals which are potentially dangerous to man and the ecosystem. The Tswana breed is more tick resistant than Simmentaler or Brahman cattle. Simmentaler cattle appeared to be the most susceptible of the three breeds to tick infestation. 
Further research is required to study the active ingredients in neem seed extract and its pharmacological action.

\section{Acknowledgements}

The assistance of D. van Zyl and R. Owen of the Statistics Department at the University of Pretoria is gratefully acknowledged. The research funding provided by A.J. Ngomuo and the cattle provided by the farmers of Serowe are greatly appreciated.

\section{References}

Butterworth, J.H. \& Morgan, E.D., 1971. Investigation of the locust feeding inhibition of the seeds of the neem tree, Azadirachta indica. J. Insect Physiol. 17, 969-977.

Farbeni, B.O., 1983. Effect of Ctenocephalides felis strongylus on performance of West African dwarf goats and sheep. Rev. Appl. Entomol. Ser. B.17, 13.

Jotwani, M.G. \& Sirca, P., 1965. Neem seed as a protectant against stored grain pest infecting wheat seed. Ind. J. Ethanol. 27, 161-167.

Kilonzo, B.S., 1986. Flea infestation of farm animals as a potential limiting factor of animal productivity in Tanzania. Proc. of TVA Sci. Conf. Arusha, 264-271.

Norval, R.A.I., Sutherst, R.W., Kurki, J., Gibson, J.D. \& Kerr, J.D., 1988. The effect of the brown ear-tick Rhipicephalus appendiculatus on the growth Sanga and European breed cattle. Vet. Parasit. 30, 149164.

Rajagopal, S. \& Nath, K., 1981. Note on the nutritive value of cake of neem seed. Ind. J. Anim. Sci. 56, 164169.

Rembold, H., Forster H. \& Czoppoelt, C.H., 1986. Structure and biological activity of Azadirachtins A and B. Proc. 3rd Int. Neem Conf. Nairobi, Kenya. pp. 149-160.

SAS, 1992. Statistical Analysis Systems user's guide (6th ed.). SAS Institute Inc., Cary, North Carolina.

Sazena, R.C., 1993. Scope of neem for developing countries. Proc. Wld Neem Conf., Febr. 1993, Bangalore, India. pp. 30-36.

Schmutterer, H., 1990. Properties and potential of natural pesticides from the neem tree. Ann. Rep. Entomol. $35,77-297$.

Scholtz, M.M., Lombard, P.E., De Bruin, D.S. \& Enslin, C.B., 1989. Eenvoudige metode vir die beraming van bosluisweerstand by beeste. S. Afr. J. Anim. Sci. 19, 121-124.

Scholtz, M.M., Spickett, A.M., Lombard, P.E. \& Enslin, C.B., 1991. The effect of tick infestation on the productivity of cows of three breeds of cattle. Onderstepoort J. Vet. Res. 58, 71-74.

Siddique, S. \& Faizi, S., 1986. Two new insect growth regulator meliacins from Azadirachta indica A. Juss (Meliasiae). J. Chem. Soc. 1, 1021.

Spickett, A.M., De Klerk, D., Enslin, C.B \& Scholz, M.M., 1989. Resistance of Nguni, Bonsmara and Hereford cattle to ticks in a bushveld region of South Africa. Onderstepoort. J. Vet. Res. 56, 245-250.

Wilps, D., 1986. Growth and adult moulting of larvae and pupae of the blowfly, Formia terae-novae in relationship to Azadirachtin concentration. Proc. $3^{\text {rd }}$ Int. Neem Conf. Nairobi, July 1986. pp. 299324.

Zebitz, C.P.W., 1986. Potential of neem seed kernel extract in mosquito control. Proc. $3^{\text {rd }}$ Int. Neem Conf. July 1986. pp. 555-573. 